\title{
A BRIEF ACCOUNT OF RIVER REHABILITATION EXPERIENCES
}

\author{
Md NuruZzaman ${ }^{1}$, ABDUllaH Al-MAMUn ${ }^{2 *}$ \\ AND MD NOOR SALLEH ${ }^{1}$ \\ ${ }^{1}$ Bioenvironmental Engineering Research Centre, \\ Department of Biotechnology Engineering \\ ${ }^{2}$ Department of Civil Engineering, \\ Faculty of Engineering, \\ International Islamic University Malaysia, \\ Jalan Gombak, 53100 Kuala Lumpur, Malaysia. \\ *Corresponding author: mamun@iium.edu.my \\ (Received: $5^{\text {th }}$ Oct. 2015; Accepted: $4^{\text {th }}$ Dec. 2016; Published online: $30^{\text {th }}$ May 2017)
}

\begin{abstract}
Rivers are vital water resources which are being altered due to urbanization and industrialization, causing threats to the environment. As a result, rehabilitation of polluted rivers has gained great importance during the last century in many countries of the world. Literature on river rehabilitation projects has been reviewed in this paper, highlighting the experiences gathered in the developed nations of the world; such as the USA, the UK, Japan, etc. Rehabilitation issues of the rivers crossing borders have also been discussed in this paper. Key lessons from different experiences in different regions have been extracted and a comparison has been made. Summarised statistics on different experiences also have been presented. Finally, some guidelines have been provided based on various experiences, which should be helpful for developed and developing nations while making their river rehabilitation efforts.
\end{abstract}

\begin{abstract}
ABSTRAK: Sungai adalah sumber air yang penting dan ia sedang diubah kerana perbandaran dan perindustrian menyebabkan ancaman besar kepada alam sekitar. Kerana itu, pemulihan sungai yang tercemar telah mendapat kepentingan yang besar kepada banyak negara di dunia sejak abad yang lalu sebagai Literatur mengenai projek-projek pemulihan sungai telah dikaji memberi tumpuan kepada bahagian yang membangun di dunia seperti Amerika Syarikat, United Kingdom, Jepun dan lain-lain. Isu-isu pemulihan sungai merentasi sempadan juga telah dibincangkan dalam kertas ini. Pengajaran penting dari pengalaman yang berbeza di rantau yang berbeza telah diekstrak dan perbandingan telah dilakukan. Statistik mengenai pengalaman yang berbeza juga telah dibentangkan. Akhirnya, beberapa garis panduan telah disediakan berdasarkan pengalaman yang berbeza, yang sepatutnya menjadi berguna untuk negara-negara maju dan membangun membuat usaha pemulihan sungai.
\end{abstract}

KEYWORDS: aquatic; ecosystem; experiences; rehabilitation; river

\section{INTRODUCTION}

The rehabilitation of stream ecosystems is a comparatively young multidisciplinary field, and the literature on aquatic rehabilitation is fragmented even if a huge number of papers is available [1]. The term restoration here refers to the return to a totally recovered natural ecosystem [2]. On the other hand, rehabilitation refers to a similar return toward natural conditions but where some elements of the original ecosystem are not recovered [2]. According to several authors [3-5], restoring components of an ecosystem is defined as 
rehabilitation. It has been stated that reviving an ecosystem to its' undisturbed natural state is termed as restoration and includes activities like enhancement, improvement, mitigation and creation of habitats, and other situations [6]. These activities are more precisely defined as rehabilitation when they do not restore an ecosystem in full scale [7]. Among the ecosystems in a jeopardized condition, the condition of rivers and wetlands is the worst [810]. The diversity of a river's ecology, the presence of habitats, and a river's potential for recreational purposes depend largely on the quality of the water. Fluvial and ecological processes occurring in the river stream sustain habitats including animal and plant life [11]. Rivers serve human beings by supplying water, mitigating floods, and receiving waste water and these activities have led to the biological death of many rivers in the world, thus attracting the attention of scientists [12].

A sustainable ecosystem, especially for fresh water systems, has become a challenge for the environmental legislators, activists, scientists and professionals. The demand for water is soaring as the rapidly increasing human population around the world competes with measures to protect stream ecosystems and ecological benefits [13]. Urban streams are important to the society as source of water supply, disposal of wastewater, and flood mitigation $[14,15]$. On the other hand, the urban rivers are being polluted by various anthropogenic activities causing ecological damages. Restoring these rivers is a huge challenge to the governments, especially for developing countries. Due to availability of sufficient knowledge on the impacts of river pollution on human life and ecology, concerned authorities are forming legislation to stop further degradation of streams and taking initiatives to recover natural river ecosystems [16].

According to Malakoff and Palmer et al. [17, 18], nearly 30 billion USD have been spent on more than 30,000 projects to rehabilitate rivers in the USA alone. Restoring rivers has become a vital and increasingly important activity in Europe as well as in North America to benefit humans as well as stream habitats $[18,19]$. In such river improvement programs, rehabilitation of habitats has become a major concern [6]. A large proportion of these projects target the rehabilitation of fisheries resources; in particular cases, huge amounts of funds are spent solely on a single species or a group of species [20]. It has been observed that large scale projects to rehabilitate streams are often far more successful than small scale projects even if large initiatives consume much time to achieve predefined objectives [21].

The objective of this paper is to illustrate the issues faced by scientists, stakeholders and other relevant bodies in river rehabilitation programs in some parts of the world. The paper does not cover the experiences of the whole world; rather, it focuses on developed countries like the USA, the UK, Japan, etc. as river rehabilitation works have been conducted mostly in the developed world. Although the rivers in developing countries are also polluted, rehabilitation efforts are rare, mainly due to lack of fund. Although the information are mainly gathered from the developed countries, the challenges experienced in those countries could deliver important lessons for the other countries who have yet to launch such programs. However, more detailed investigation should be done in developing countries to predict possible difficulties that are not faced by developed countries.

\section{BACKGROUND}

Many Japanese rivers suffered from rapid urbanization, regulation of flow, loss of habitat, and appearance of huge amounts of exotic plants [22, 23]. The $136 \mathrm{~km}$ long Tama River in Japan underwent geomorphic transformation from a large braided river to a single thread channel due to the Hamura weir, a massive excavation of gravel, and a drastic decline of sediment supply [22-24]. Extending the width of the channel and increasing 
sedimentation supply were necessary to rehabilitate the river. Downstream of the Hamura weir, gravel was artificially added to increase the sediment supply. Widening of the channel was done at two sites. Although there are no scientific evaluations performed yet, there are certain signs of recovery. Lakes are considered an integral part of river systems. Lakes are also polluted by human activities which cause environmental degradation. The Kasumigaura lake in Japan turned into a dead lake within a mere 30 years. Emergent plants decreased by half and submerged plants were very few in number in 2000 while the transparency depth decreased drastically. Excavated bottom sediments were used in the rehabilitation project of the lake. Locally extinct plants were recovered using natural seed banks [22].

Helfield et al. [25] picked out the Pite river in Sweden to check the effects of river rehabilitation on riparian biodiversity in secondary channels. They stated that the regained stream could not revive flood adapted plants; this is probably due to the short time elapsed since rehabilitation. However, previous studies illustrated quick responses to similar programs in single channel tributaries, but they have shown how rehabilitation results may differ depending upon climatic, ecologic, and hydrologic factors, demonstrating the necessity of site-specific rehabilitation measures.

Bond and Lake [26] discussed several issues which have direct influence on the success of a stream habitat rehabilitation project. Impediments to colonization, temporal shifts in habitat use, introduction of new species, massive processes, and inaccurate scales of rehabilitation are the items explained by them. The initial goal was to alert ecologists as well as other stakeholders, but they have also thrown light on scopes created by habitat rehabilitation. The interaction between flow and form of the Lower Missouri River was performed by modeling four different combinations of modern and historical flow and forms [27]. They concluded that rehabilitation programs that tend towards the historical condition have the potential to increase topographic diversity and sensitivity of the availability of the habitat to flow regime.

Palmer et al. [28] insist that there is a paucity of documentation of river rehabilitation projects and as a consequence, crucial information that may trigger the success of such programs is unpublished. Therefore, they have written an article providing an overview, reflecting on lessons learned that are critical to implement these projects. They further state that investing a tiny fraction of the funds allocated for river rehabilitation projects to keep records on factors conducive to success will immensely benefit such types of projects.

Koehn [29] gave an overview on fish habitat rehabilitation in the Murray-Darling basin focusing on present and past management issues, attitude of people and stakeholders, support from the local people, and trends in rehabilitation activities. He suggested several points, categorizing them into management, science, and community. Enhancing interplay between policy makers and scientists and focusing on ecosystem outcomes were two of his vital suggestions under managerial issues. He added that scientific knowledge should be disseminated properly to the local practitioners and that the community should be stakeholders in rehabilitation projects.

In many European countries, including Switzerland, reducing flood risks through ecological rehabilitation has been implemented. Though urban river revival programs are gambled by major risks and challenges, they can enhance societal life standards and be appreciated by all people [22]. Table 1 presents focal points of rehabilitation works with their objectives, scopes, and methods. Most of the river rehabilitation works mainly focus on water and riparian zone [30]. However, based on scope, objective, and other relevant issues, rehabilitation works are also done on aesthetics, habitats, and flood mitigation. 


\section{LESSONS LEARNED}

Proper and effective methods cannot be devised without sufficient information on river rehabilitation and lack thereof hinders a perfect guidance [31-33]. Thus, in this section of the article, experiences gathered from river rehabilitation programs from different parts of the world are briefly summarized.

Table 1: Rehabilitation works and their objectives, scopes, and methods

\begin{tabular}{llll}
\hline $\begin{array}{l}\text { Rehabilitation } \\
\text { Target }\end{array}$ & \multicolumn{1}{c}{ Objective } & \multicolumn{1}{c}{ Scope } & \multicolumn{1}{c}{ Methods } \\
\hline Water & $\begin{array}{l}\text { To achieve } \\
\text { standard water } \\
\text { quality }\end{array}$ & $\begin{array}{l}\text { Instream habitats, } \\
\text { recreation, water } \\
\text { consumption etc. }\end{array}$ & 1. Removing point source pollution \\
2. Altering land use of catchment
\end{tabular}

\subsection{The USA Experience}

The rehabilitation efforts in the USA are generally launched with a view to improving riparian zones, ameliorating water quality, improving stream habitats, stabilizing banks, etc. Few projects are analyzed deeply, and very few of them are audited for ecological achievement [34]. It is truly essential to accurately judge how much the rivers benefit from rehabilitation efforts and the authorities need to gather proper information regarding the potency of their strategies. However, a huge program, the National River Restoration Science Synthesis (NRRSS), has been launched by the USA incorporating freshwater scientists and their river rehabilitation experiences [34] to find common elements leading to river rehabilitation success as well as to compensate for a lack of information in ecological sciences that should be investigated for more fruitful rehabilitation activities [18]. According to the US National Research Council [5], in the twentieth century, the mighty Missouri river was altered by the construction of dams, reservoirs, and navigation channels for commercial purposes, all to produce many social benefits. Unfortunately the toll for this was paid by the loss of habitats and extinction of many fish species [5]. However in the USA, questions relating social and economic factors are likely to come to the forefront while taking any river rehabilitation action e.g. what will be the effect on local economies due to floodplain land acquisition or recovery of ecosystems. In these situations, US NRC [5] suggests that the policy makers must include the social and economic effects due to any action taken along with the scientific factors. The interaction among scientific and nonscientific factors is observed in the Missouri river sediment management program. 
It is a daunting task for decision makers to remain within the boundaries set by the scientists, local communities, and stakeholders. However, to use the scientific knowledge efficiently, it is a requisite for all parties to admit different aspects of science and policy and consider the lack of information about the river's natural system. Lack of information may occur due to the absence of any monitoring or evaluation phase of the river rehabilitation programs. Many authors have described monitoring as part of a learning cycle and also have suggested adaptive management $[18,19,35]$. In the USA, evaluation or monitoring were done only on $10 \%$ of the projects in the national database [36]. Alexander and Allan [37] mentioned that record keeping activities should be standardized and findings disseminated properly to ensure that the projects are economical and rehabilitation effectiveness is maximized. Reeves et al. [38] expressed their opinion that response to a rehabilitation program, often requires monitoring of the said river for not less than 10 years.

\subsection{The UK Experience}

River rehabilitation in the UK started in the late 1980s to ensure a strong foundation for improved river management in the future [39]. However, analysis made by Wharton and Gilvear reported that river rehabilitation projects inside the UK are piecemeal and need to be approached as part of a catchment-wide strategy. They also predicted that this initiative can cause multiple benefits to the ecological status of a river, including flood risk minimization [39]. They also emphasized on combined stream and land management. Bannister et al. [40] stated that 35 projects in the UK were identified as catchment scale based projects but none of them was a truly integrated catchment scale river rehabilitation. They concluded that Catchment Scale River Restoration must be incorporated into these schemes to achieve higher ecological success and to address flooding problems. It was their recommendation that literature review should be extended beyond the UK and a detailed database be prepared containing critical information to appropriately use necessary tools.

\subsection{Japanese Experience}

Nakamura gave an overview and perspective of river rehabilitation projects in Japan [22]. He also summarized the drawbacks as well as the key factors to successfully complete these initiatives in different situations. His observations are illustrated here, learned from experiences of rehabilitation efforts taken in Japan. In the USA, along with Europe, most river reinstatement projects are supported by financially and technically well-off organizations like WWF, IUCN, TNC etc., whereas in Japan, such initiatives are mainly launched by small NGOs [22]. However, these organizations have the potential to trigger large projects by connecting local people with the river authorities, and scientists as well, even if they have financial and technical limitations. The largest lake rehabilitation project in Japan for lake Kasumigaura was initiated by a local NGO called "Asaza Project". Another local NGO initiated the nationwide "Nature Oriented River Works" program in 1990 in Japan [22]. These examples in japan are models for developing countries because the NGOs are comparatively small in size and few in numbers. In Japan, resurrecting rivers is toilsome work because of its catchment characteristics, floodplain, dynamic stream, and sediment regime [22]. The reinstatement of the Tama River confirms that there is no conflicting issue between the protection of property and people and the betterment of ecosystems.

\subsection{Spanish Experience}

The European research project FORECASTER (Facilitating the application of Output from Research and Case Studies on Ecological Responses to hydro-morphological degradation and rehabilitation) was formulated between 2008 and 2010 with a view to assessing research outcomes from various parts of the world and reviewing case studies on 
the hydromorphological deterioration and placing hydromorphology in river rehabilitation schemes [16]. Del Tánago et al. analyzed case studies of sixty Spanish river rehabilitation programs and concluded that there is a propensity to building river structures overlooking improvement of river processes like floodplain management, flow regime, etc. [16]. In Mediterranean areas, insufficient water quantity and inferior water quality exacerbates the rivalry for water resources hindering rural development [41, 42]. There is enough data on rehabilitation theory and practice from humid-temperate regions [43], whereas there is a huge lack of information from Mediterranean areas where water is scarce and many restraints reduce river rehabilitation possibilities.

In Spain, difficulties for administrative staff to apply river rehabilitation guidelines have been identified. Many of the identified difficulties were due to lack of experience as well as lack of environmental background [16]. They also mentioned that training is very essential in this case and involvement of scientific community and stakeholders will be extremely worthy. They continued that the measures taken (vegetation in the riparian zone, fish migration, elimination of weirs, etc.) to revive Spanish rivers are not meeting the demand for better ecological status. In addition, Spanish rivers are strictly regulated without determining flow regulation effects. However, distribution of proper in-stream limiting other consumptive water uses seems to be fruitful, symbolizing a major issue in Mediterranean countries for river rehabilitation projects where river management must necessarily be combined with human and environmental needs. Mora'n-Tejeda et al. [44] argue that the strain may rise due to climate alteration as well as urban population growth.

\subsection{Danish Experience}

The Danish "Wet Meadow" program demonstrated that the objectives or goals of a river reinstatement program are to be definite and explicitly described while the outcomes expectation should be justified [45]. In this project a pre-drainage was revived in reclaimed meadows to heighten denitrification. Only a little fraction of the total budget of 70 million Euros for the project was spent for construction, whereas $80 \%$ of the allocated fund was spent to compensate farmers and other purposes. A vital measure in Danish projects is the enhanced migration facility for salmonids [45]. Fish passages give little room to fishes for a successful migration [46] whereas replacing weir or dam with a riffle paves the way for fish to fish migrate easily [34]. Again, there is a huge difference between successful migration and successful recolonization. Salmonid population can be sustained depending upon the availability and quality of breeding region habitats. The upstream reaches should also be revived where the breeding areas of the fish are destroyed by ochre and sand [34].

\subsection{Australian Experience}

Similar to other countries, many Australian streams are also polluted and millions of dollars are allocated every year to stop the aggression and revive rivers [45]. Based on the experiences of the USA, Spain, and other developed countries, few Australian river rehabilitation projects are well judged before the initiation of the projects [45]. The Cooperative Research Center for Freshwater Ecology (CRCFE) has been established, aiming to provide crucial information to maximize practical rehabilitation efforts [47]. The precise objective of the research is to interpret various ecological processes helping to regain polluted rivers and disturbed stream ecosystems [45].

\subsection{Malaysian Experience}

Pollution of Malaysian rivers is due to the effect of rapid urbanization and expansion of agriculture. Malaysian rivers have become overstressed and have been pushed to their limits to provide life sustaining resources [48]. It is noted that out of 91 monitored rivers in 
Malaysia, only three were very polluted in 1987. Whereas in the year 2002, out of 120 rivers monitored, 22 were found to be very polluted. The Klang river in Malaysia underwent seven years of clean-up programs and demonstrated encouraging results, yet some aspects of the project were frustrating like solid waste disposal into the river [48]. The study conducted by Chan et al. illustrated that river rehabilitation programs in Malaysia can only be successful with a joint venture of government, local people and NGOs [48]. A case study conducted by Chun et al. revealed that most people in Malaysia are willing to participate in river conservation programs [49]. However, more effective initiatives are necessary to see big changes in the river ecology.

\subsection{Trans-boundary Rivers}

\subsubsection{Danube River}

The mighty Danube River extends from Germany to the Black sea reaching nearly 3000 $\mathrm{km}$ in length. It underwent extreme alteration due to massive scale hydro-engineering projects for hydropower production in the second half of $20^{\text {th }}$ century [50]. Even if the floodplain rehabilitation of Danube involved multidisciplinary planning by ecologists, engineers, hydrologists, and nature conservationists, it was considered a learning step for future improvement. Hydrological connectivity between the Danube and its floodplain was considered one of the most vital steps in the rehabilitation program [51]. According to [52], rehabilitating its hydrological connectivity will maintain a higher productivity. Among several project goals, improvement of water quality is in dire need of international coordination and commitment. However, it was concluded that regaining the high diversity of Danube flood plain can be fully understood by reconstituting the fluvial dynamics and connectivity gradients instead of rehabilitating individual species or group [51].

\subsubsection{Rhine River}

The Rhine River is comparatively smaller in length than that of the Danube which stretched 1300 km over Switzerland, Austria, Germany, France, Luxembourg, Belgium, and the Netherlands [53]. Regulation and normalization of main and tributary channels caused habitat reduction and other impacts in this river [54]. It was found that connectivity and redevelopment of secondary channels were necessary to rehabilitate the river [54]. On the other hand, the disappearance of salmon from the Rhine in the mid- $20^{\text {th }}$ century due to promotion of navigation and hydropower on the Rhine by the Netherlands showed that one-sided activities without any collaborative approach are a threat to trans-boundary river rehabilitation [53]. Vaate [55] mentioned several reasons for improved water quality in the Rhine in the late 1970s, among which international agreements and implementation of environmental protection laws were two vital reasons.

\subsubsection{Meuse River}

The $870 \mathrm{~km}$ long Meuse river belonging to France, Belgium, Luxembourg, Germany and the Netherlands, [53] suffered from extreme river engineering and industrial waste water disposal like other European rivers [55]. Countries sharing the Meuse river basin united in 1994, forming the International Commission on Protection of the Meuse river (ICPM). The Meuse Action Program was launched in 1997 focusing mainly on water quality improvement. Unfortunately, ICPM did not set any specific target for pollution minimization and improvement of the ecology [55].

\subsubsection{Hirmand Hamoon Wetland}

Iran and Afghanistan share a wetland named Hamoon that receives water from the Hirmand (Helmend) river; a very important and unique freshwater source to both countries 
[56]. The implementation of the project, launched by the Afghanistan government to expand agriculture under their river jurisdiction during the mid- $20^{\text {th }}$ century led to the degradation of the wetland [56]. However, in 1973, the Hirmand (Helmend) water treaty was signed between the two sides through which lawful steps were taken to rehabilitate the wetland. Furthermore, international organizations like UNEP and funding agencies such as GEF came forward to help revive the wetland [56]. Despite Iranian the noteworthy investment of huge sums of money and technical support to rehabilitate the wetland, the results could be far better if cooperation from Afghanistan were available [56].

\subsubsection{Jordan River}

The Jordan river, which is shared by Jordan, Syria, Lebanon, Israel, and Palestine, is suffering from a scarcity of water and other degradations due to excessive exploitation and regulation of water [57]. Over exploitation, pollution, and lack of regional management turned this mighty river in to a trickle [58]. Israel and Jordan signed a peace treaty promising that they will work together to rehabilitate the river $[58,59]$ and Friends of the Earth Middle East (FoME) was founded in that same year [58]. However, neither government has taken any concrete step to revive the freshwater until now [58, 59]. Palestinians are restricted from the right to extract water from the Jordan river by Israel while FoME believes that transboundary collaboration is the only hope of reviving the river to its' pre-disturbed state [58]. The key lessons learned from different countries as well as cross-border rivers are summarized in Table 2.

Table 2: Summary of key lessons learned

\begin{tabular}{|c|c|}
\hline Country/River/Wetland & Key Lessons \\
\hline USA & $\begin{array}{l}\text { - Tracing out common elements of successful river rehabilitation programs } \\
\text { - Considering social and economic factors } \\
\text { - Monitoring of rehabilitated rivers and disseminating the findings }\end{array}$ \\
\hline UK & $\begin{array}{l}\text { - Need catchment scale river rehabilitation } \\
\text { - Managing stream and land together } \\
\text { - Preparation of detailed database }\end{array}$ \\
\hline Japan & - Role of small NGOs to trigger large scale rehabilitation projects \\
\hline Spain & $\begin{array}{l}\text { - Difficulties among administrative staffs due to lack of experience and } \\
\text { environmental background } \\
\text { - Arrangement of proper training }\end{array}$ \\
\hline Denmark & $\begin{array}{l}\text { - Definite objectives of rehabilitation programs and justified outcome } \\
\text { expectations }\end{array}$ \\
\hline Australia & - Proper judgment before initiation of any rehabilitation project \\
\hline Malaysia & $\begin{array}{l}\text { - Need joint venture of government, local people and NGOs } \\
\text { - Willingness of Malaysian people to participate in conservation programs }\end{array}$ \\
\hline Danube river & - International co-ordination and commitment \\
\hline Rhine river & $\begin{array}{l}\text { - One sided activities- a threat to river rehabilitation } \\
\text { - International agreement and implementation of environmental laws }\end{array}$ \\
\hline Meuse river & - Fixing specific target for pollution reduction and improvement of ecology \\
\hline $\begin{array}{l}\text { Hirman-Hamoon } \\
\text { Wetland }\end{array}$ & $\begin{array}{l}\text { - Equal contribution of both sides sharing the water and land } \\
\text { - Help from international organization }\end{array}$ \\
\hline Jordan river & $\begin{array}{l}\text { - Concrete action from all countries involving the river } \\
\text { - Equal opportunity for all sharing countries }\end{array}$ \\
\hline
\end{tabular}




\subsection{Comparison of Different Experiences}

Table 3 presents the similarities and differences between rehabilitation experiences, based on the experiences of the different countries mentioned above. Different countries undergo different experiences on a same issue. For instance, rehabilitation efforts in developed countries like the USA and UK are mainly funded by large organizations whereas, despite Japan being a developed country, small NGOs played vital role in rehabilitation efforts. Differences are also observed in other issues like public opinion, catchment scale rehabilitation effort, upstream reach rehabilitation, ecological emphasis, international co-operation, and rehabilitation objectives in different countries. On the other hand, in connection with documentation of rehabilitation works, monitoring, the necessity for prior investigation, and unilateral activities, most of the countries underwent similar experiences.

Table 3: Comparison of different rehabilitation experiences

\begin{tabular}{llll}
\hline Comparison & \multicolumn{1}{c}{ Experience } & \multicolumn{2}{c}{ Type } \\
\hline & Funding & By large organizations & By small NGOs \\
& Public Opinion & Crucial & Trivial \\
& Catchment study & Performed & Excluded \\
Differences & Upstream reach rehabilitation & Considered & Ignored \\
& Ecological study & Emphasized & Disregarded \\
& International Co-operation & Existing & Lacking \\
& Rehabilitation objectives & Specific & Vague \\
\hline \multirow{5}{*}{ Similarities } & Documentation & \multicolumn{2}{c}{ Not enough } \\
& Monitoring & \multicolumn{2}{c}{ Lacking } \\
& Prior investigation & \multicolumn{2}{c}{ Very important } \\
& Unilateral activities & \multicolumn{2}{c}{ A threat } \\
\hline
\end{tabular}

The experiences mentioned above, and compared in the table, have been selected based on fundamental requirements for any project and special requirements for river rehabilitation work. For instance, funding and public opinion are basic driving factors for any kind of project. On the other hand, study of the catchment of the river under consideration, is a special requirement for a river rehabilitation project. Furthermore, for local rivers, international co-operation is not always essential, whereas for trans-boundary rivers, international co-operation becomes very crucial.

\section{STATISTICS ON RIVER REHABILITATION EXPERIENCES}

Figure 1 demonstrates monitoring of river rehabilitation projects in several parts of the USA. Bernhardt (2005) suggested that in the US, projects having higher budget are more likely to be monitored [60] due to availability of adequate fund for the monitoring activities and data archiving. Though the tendency of a project being monitored can be observed in some areas, a significant or very strong relationship cannot be concluded from such information (Fig. 1). Berhardt et al. [36] reports that on average, 10\% of the projects are monitored in the USA. Detail statistics in most of the other countries are not available. 


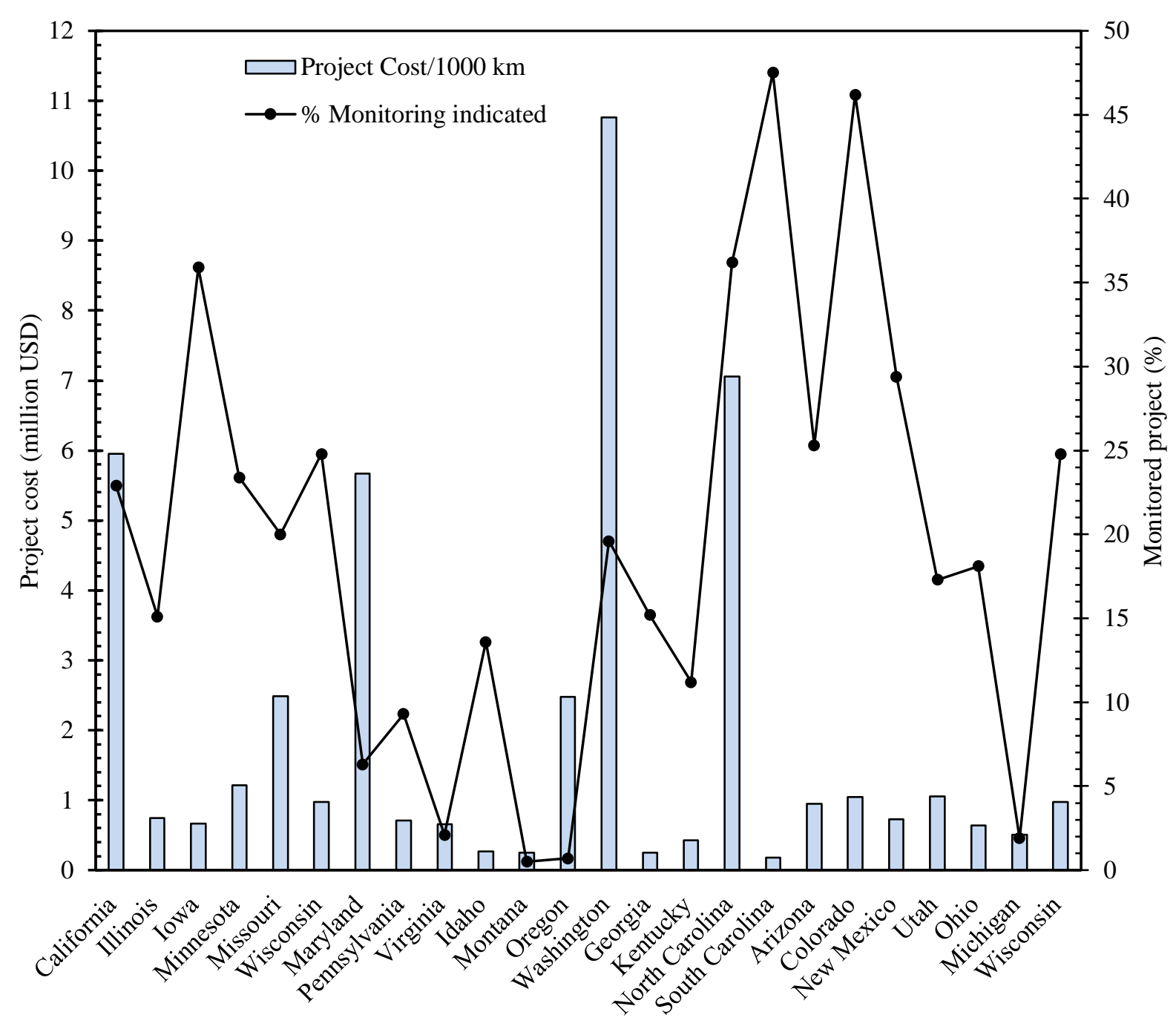

Fig. 1: Monitored projects in the USA [60].

From Fig. 2, it is evident that within 1970 and 1990, the number of river rehabilitation projects recorded and documented was almost nil. Even though, after 1990, there was a rise in number, many projects have gone unrecorded and they affected the succeeding projects due to lack of information. The same goes for newspaper and scientific articles. However, the number of newspaper and scientific articles is not anywhere near to the number of recorded projects.

Bernhardt et al. interviewed 317 river rehabilitation project managers in the USA and compared the data with the NRSS top projects [61]. Part of that data is shown in Table 4. The issue of interest here is public involvement, which is where almost half of a community (49\%) was engaged with ongoing river rehabilitation projects in the USA. Chun et al. also reported the willingness of the Malaysian people in river rehabilitation programs in their respective areas [49]. However, the precise data is not available for Malaysia. Another aspect is the number of sponsors or funders, which is on average 3.6 funders for each project. 


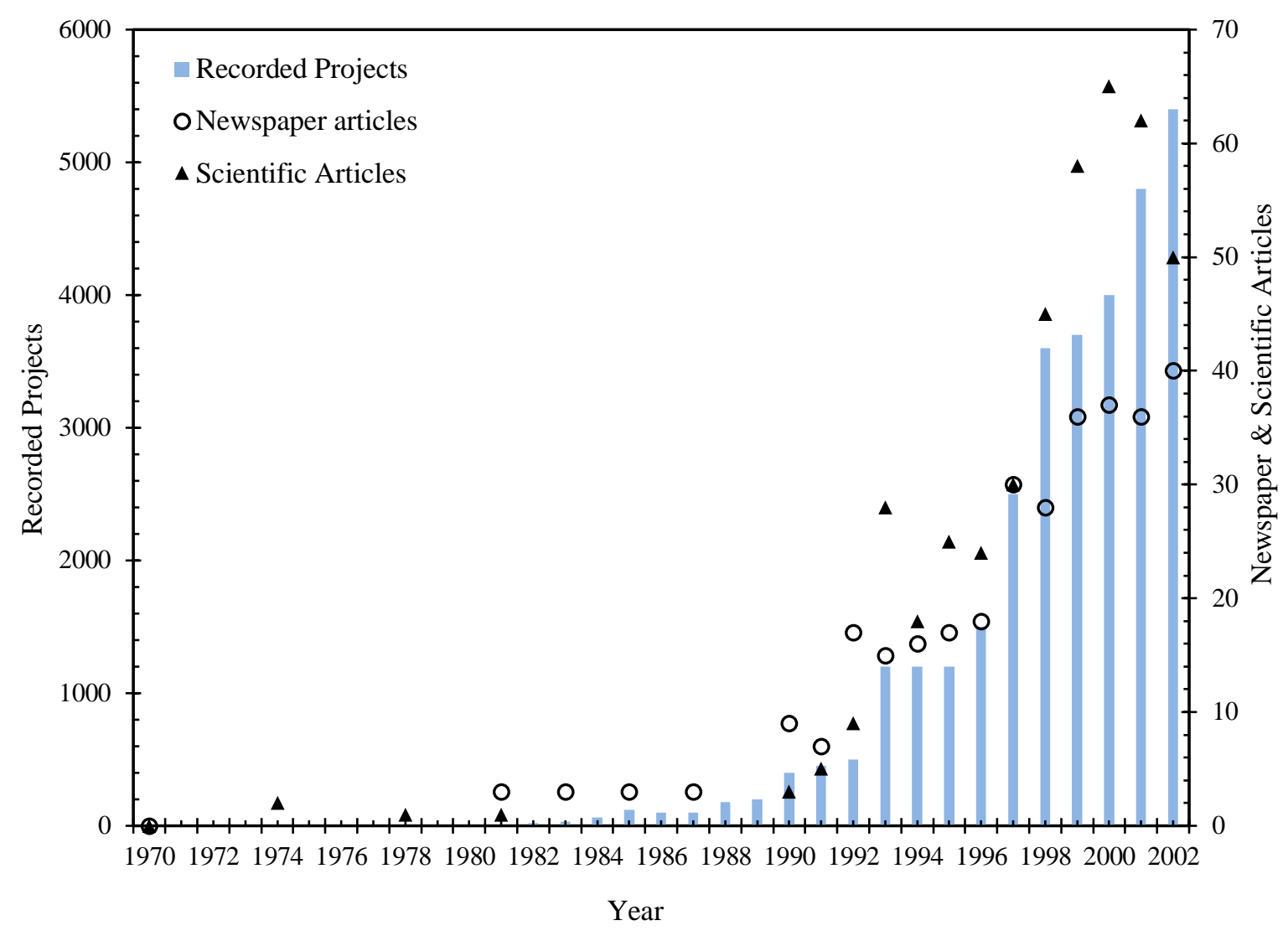

Fig. 2: National River Restoration Science Synthesis (NRSS) Record of River Rehabilitation Projects in the USA [36].

Table 4: Interview statistics for 317 US river rehabilitation projects

\begin{tabular}{lc}
\hline \multicolumn{1}{c}{ Particular } & Value \\
\hline Expenditure range & $\$ 140-\$ 116$ million \\
Expenditure (median) & $\$ 150,000$ \\
$\begin{array}{l}\text { Rehabilitation length } \\
\text { (median) }\end{array}$ & $914 \mathrm{~m}$ \\
Average number of sponsors & 3.6 \\
$\begin{array}{l}\text { Average number of } \\
\text { partners/agencies/entities }\end{array}$ & 7.1 \\
Public participation $(\%)$ & 49 \\
\hline
\end{tabular}

Figure 3 illustrates guidelines for future river rehabilitation work. As the tasks shown in the horizontal boxes are done with the action shown in the vertical boxes, a river rehabilitation program is expected to shift to the right of the horizontal axes. The outcomes of each action during different stages of rehabilitation are given in the horizontal axis, which starts at failure and ends at ultimate success. 


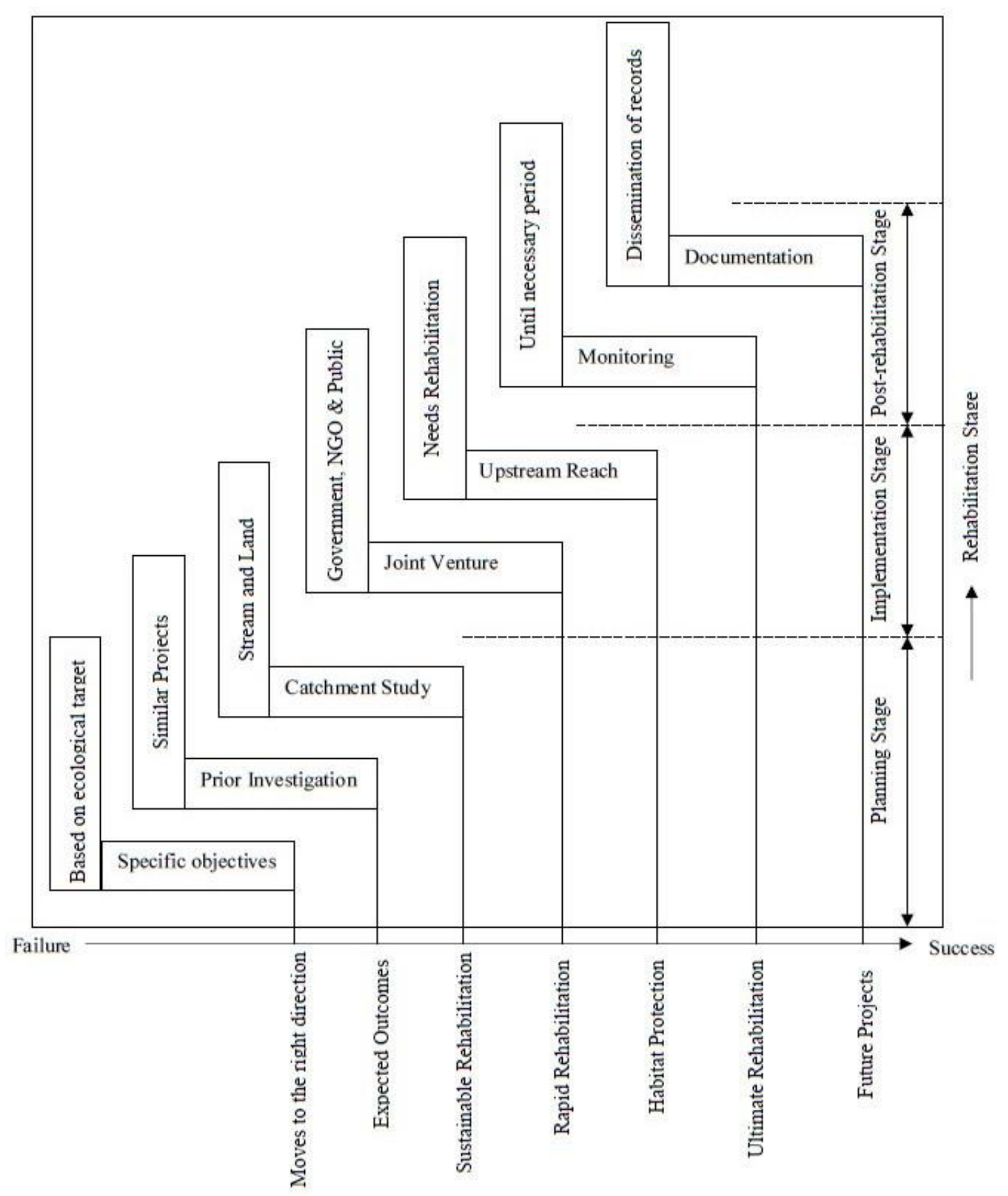

Fig. 3: Guideline chart for future river rehabilitation based on different experiences.

\section{CONCLUSIONS}

This paper summarizes the experiences gathered in river rehabilitation programs in the developed countries and also for some trans-boundary rivers. The lessons learned from those countries are not just local, rather these experiences will serve vital information for river rehabilitation programs in the developing countries as well. This paper contributes to the knowledge of river rehabilitation experiences by enabling the readers to compare issues faced in the past. The comparison of different experiences can be regarded as a birds eye view for stakeholders, which will help them to take proper decisions. Therefore, this paper is of great importance for the legislators, stakeholders, funders, engineers, and managers involved in such kind of projects. Some guidelines have also been provided based on the past experiences recorded in the literature. 


\section{REFERENCES}

[1] Buijse AD, Coops H, Staras M, Jans L, Van Geest G, Grift R, Ibelings BW, Oosterberg W, Roozen FC. (2002) Restoration strategies for river floodplains along large lowland rivers in Europe. Freshwater biology. 47(4):889-907.

[2] Rutherfurd ID, Marsh N, Jerie K. (2000) A rehabilitation manual for Australian streams. vol. 1.: Land and Water Resources Research and Development Corporation and Cooperative Research Centre for Catchment Hydrology Canberra, Australia.

[3] Rhoads BL, Wilson D, Urban M, Herricks EE. (1999) Interaction between scientists and nonscientists in community-based watershed management: emergence of the concept of stream naturalization. Environmental management, 24(3):297-308.

[4] Sparks RE. (1995) Need for ecosystem management of large rivers and their floodplains. BioScience, 45(3):168-182.

[5] Staff IoM. and Staff, NRC. (2002) The Missouri River Ecosystem: Exploring the Prospects for Recovery. National Academies Press.

[6] Roni P, Beechie TJ, Bilby RE, Leonetti FE, Pollock MM, Pess GR. (2002) A review of stream restoration techniques and a hierarchical strategy for prioritizing restoration in Pacific Northwest watersheds. North American Journal of Fisheries Management, 22(1):1-20.

[7] Stanford JA, Ward J, Liss WJ, Frissell CA, Williams RN, Lichatowich JA, Coutant, CC. (1996) A general protocol for restoration of regulated rivers. US Department of Energy Publications: 43.

[8] Brinson MM. Malvárez AI. (2002) Temperate freshwater wetlands: types, status, and threats. Environmental conservation, 29(2):115-133.

[9] Malmqvist B, Rundle S. (2002) Threats to the running water ecosystems of the world. Environmental conservation, 29(2):134-153.

[10] Tockner K, Stanford JA. (2002) Riverine flood plains: present state and future trends. Environmental conservation, 29(3):308-330.

[11] Peters NE, Meybeck M. (2000) Water quality degradation effects on freshwater availability: impacts of human activities. Water International, 25(2):185-193.

[12] Paul MJ. Meyer JL. (2001) Streams in the urban landscape. Annual review of Ecology and Systematics: 333-365.

[13] Assessment ME, Ecosystems and human well-being. vol. 200. 2003: Washington, DC: Island Press.

[14] Morley SA, Karr JR. (2002) Assessing and restoring the health of urban streams in the Puget Sound basin. Conservation Biology, 16(6):1498-1509.

[15] Walsh CJ. (2000) Urban impacts on the ecology of receiving waters: a framework for assessment, conservation and restoration. Hydrobiologia, 431(2):107-114.

[16] Del Tánago MG, De Jalón DG, Román M. (2012) River restoration in Spain: theoretical and practical approach in the context of the European Water Framework Directive. Environmental management, 50(1):123-139.

[17] Malakoff D. (2004) The river doctor. Science, 305: 937.

[18] Palmer M, Bernhardt E, Allan J, Lake P, Alexander G, Brooks S, Carr J, Clayton S, Dahm C, Follstad Shah J. (2005) Standards for ecologically successful river restoration. Journal of Applied Ecology, 42(2):208-217.

[19] Downs PW, Kondolf GM. (2002) Post-project appraisals in adaptive management of river channel restoration. Environmental Management, 29(4):477-496.

[20] Roni P, Hanson K, Beechie T. (2008) Global review of the physical and biological effectiveness of stream habitat rehabilitation techniques. North American Journal of Fisheries Management, 28(3):856-890.

[21] Lake P. (2001) On the maturing of restoration: linking ecological research and restoration. Ecological Management \& Restoration, 2(2):110-115.

[22] Nakamura K. (2008) River restoration efforts in Japan: overview and perspective. Public Works Research Institute, Japan. http:// www. pwri. go. jp/ eng/ activity/ pdf/ reports/k. nakamura. 80601. 
[23] Shimatani Y. (2003) Restoration of river channel morphology at the Nagata Area in the Tama River. Ecology and Civil Engineering, 5(2):233-240.

[24] Minagawa T, Shimatani Y. (1999) Study of indices for river restoration on braided river. Environmental Systems Research, 27:237-246.

[25] Helfield JM, Engström J, Michel JT, Nilsson C, Jansson R. (2012) Effects of river restoration on riparian biodiversity in secondary channels of the Pite River, Sweden. Environmental management, 49(1):130-141.

[26] Bond N, Lake P. (2003) Local habitat restoration in streams: constraints on the effectiveness of restoration for stream biota. Ecological Management \& Restoration, 4(3):193-198.

[27] Jacobson RB, Galat DL. (2006) Flow and form in rehabilitation of large-river ecosystems: an example from the Lower Missouri River. Geomorphology, 77(3):249-269.

[28] Palmer M, Allan JD, Meyer J, Bernhardt ES. (2007) River restoration in the twenty-first century: data and experiential knowledge to inform future efforts. Restoration Ecology, 15(3):472-481.

[29] Koehn, J. (2004) Rehabilitation of fish habitats in the Murray-Darling Basin-where have we been and where are we going. in Native Fish Habitat Rehabilitation and Management in the Murray-Darling Basin: Statement, Rrecommendations and Supporting Papers. Proceedings of a workshop held in Albury, 2004.

[30] Wohl E, Angermeier PL, Bledsoe B, Kondolf GM, MacDonnell L, Merritt DM, Palmer MA, Poff NL, Tarboton D. (2005) River restoration. Water Resources Research, 41(10).

[31] Chapman PM. (2000) The Sediment Quality Triad: then, now and tomorrow. International Journal of Environment and Pollution, 13(1-6):351-356.

[32] Frissell CA, Nawa RK. (1992) Incidence and causes of physical failure of artificial habitat structures in streams of western Oregon and Washington. North American Journal of Fisheries Management, 12(1):182-197.

[33] Reeves G, Hall J, Roelofs T, Hickman T, Baker C. (1991) Rehabilitating and modifying stream habitats.

[34] Madsen J. (1995) Impacts of disturbance on migratory waterfowl. Ibis. 137(s1): S67-S74.

[35] Jungwirth M, Muhar S, Schmutz S. (2002) Re-establishing and assessing ecological integrity in riverine landscapes. Freshwater Biology, 47(4):867-887.

[36] Bernhardt E, Palmer M, Allan J, Alexander G, Brooks S, Carr J, Dahm C, Follstad-Shah J, Galat D, Gloss S. (2005) Restoration of US rivers: A national synthesis. Science, 308:636637.

[37] Alexander GG, Allan JD. (2006) Stream restoration in the Upper Midwest, USA. Restoration Ecology, 14(4):595-604.

[38] Reeves G, Hohler D, Hansen B, Everest F, Sedell J, Hickman T, Shively D. (1997) Fish habitat restoration in the Pacific Northwest: fish creek of Oregon. Watershed Restoration: Principles and Practices, pp 335-359.

[39] Wharton G, Gilvear DJ. (2007) River restoration in the UK: Meeting the dual needs of the European Union Water Framework Directive and flood defence? International Journal of River Basin Management, 5(2):143-154.

[40] Bannister N, Mant J, Janes M. (2005) A review of catchment scale river restoration projects in the UK. The River Restoration Centre, Report-December.

[41] Grantham TE, Merenlender AM, Resh VH. (2010) Climatic influences and anthropogenic stressors: an integrated framework for streamflow management in Mediterranean-climate California, USA. Freshwater Biology, 55(s1):188-204.

[42] Hooke J. (2006) Human impacts on fluvial systems in the Mediterranean region. Geomorphology, 79(3):311-335.

[43] Feld CK, Birk S, Bradley DC, Hering D, Kail J, Marzin A, Melcher A, Nemitz D, Pedersen ML, Pletterbauer F. (2011) From natural to degraded rivers and back again: a test of restoration ecology theory and practice. Advances in Ecological Research. 44:119-209.

[44] Morán-Tejeda E, Ceballos-Barbancho A, Llorente-Pinto JM. (2010) Hydrological response of Mediterranean headwaters to climate oscillations and land-cover changes: The mountains of Duero River basin (Central Spain). Global and Planetary Change, 72(1):39-49. 
[45] Madsen B, Boon P, Lake P, Bunn S, Dahm C, Langford T, Zalewski M. (2006) Ecological principles and stream restoration. Internationale Vereinigung fur Theoretische und Angewandte Limnologie Verhandlungen, 29(4):2045-2050.

[46] Aarestrup K, Koed A. (2003) Survival of migrating sea trout (Salmo trutta) and Atlantic salmon (Salmo salar) smolts negotiating weirs in small Danish rivers. Ecology of Freshwater Fish, 12(3):169-176.

[47] Cottingham P, Thoms M, Quinn G. (2002) Scientific panels and their use in environmental flow assessment in Australia. Australian Journal of Water Resources, 5(1):103-111.

[48] Chan NW, Abdullah AL, Ibrahim AL, Ghazali S. (2003) River pollution and restoration towards sustainable water resources management in Malaysia.

[49] Chun MH, Sulaiman WNA, Samah MAA. (2012) A case study on public participation for the conservation of a tropical urban river. Polish Journal of Environmental Studies, 21(4):821829.

[50] Schiemer F, Baumgartner C, Tockner K. (1999) Restoration of floodplain rivers: The'Danube restoration project'. Regulated Rivers: Research \& Management, 15(1):231-244.

[51] Tockner K, Schiemer F, Ward J. (1998) Conservation by restoration: the management concept for a river-floodplain system on the Danube River in Austria. Aquatic Conservation: Marine and Freshwater Ecosystems, 8(1):71-86.

[52] Hein T, Baranyi C, Herndl GJ, Wanek W, Schiemer F. (2003) Allochthonous and autochthonous particulate organic matter in floodplains of the River Danube: the importance of hydrological connectivity. Freshwater Biology, 48(2):220-232.

[53] Huisman P, De Jong J, Wieriks K. (2000) Transboundary cooperation in shared river basins: experiences from the Rhine, Meuse and North Sea. Water Policy, 2(1):83-97.

[54] Van den Brink F, Van der Velde G, Buijse A, Klink A. (1996) Biodiversity in the lower Rhine and Meuse river-floodplains: its significance for ecological river management. Netherland Journal of Aquatic Ecology, 30(2-3):129-149.

[55] Vaate A. (2003) Degradation and recovery of the freshwater fauna in the lower sections of the rivers Rhine and Meuse. 2003: [sn]. ISBN 90-5808-844-8.

[56] Najafi A, Vatanfada J. (2011) Environmental challenges in trans-boundary waters, case study: Hamoon Hirmand Wetland (Iran and Afghanistan). International Journal of Water Resources and Arid Environments, 1(1):16-24.

[57] Venot J-P, Molle F, Courcier R. (2008) Dealing with closed basins: the case of the Lower Jordan River Basin. Water Resources Development, 24(2):247-263.

[58] Mehyar M, Al Khateeb N, Bromberg G, Koch-Ya'ari E. (2014) Transboundary cooperation in the Lower Jordan River Basin. Water and post-conflict peacebuilding.

[59] Gafny S, Talozi S, Al Sheikh B. (2010) Towards a Living Jordan River.

[60] Bernhardt E. (2005) National River Restoration Science Synthesis (NRRSS) statistics page for all node areas. US Geological Survey. Available: nrrss. nbii. gov.(December 2005).

[61] Bernhardt ES, Sudduth EB, Palmer MA, Allan JD, Meyer JL, Alexander G, Follastad-Shah J, Hassett B, Jenkinson R, Lave,R. (2007) Restoring rivers one reach at a time: results from a survey of US river restoration practitioners. Restoration Ecology, 15(3):482-493. 